\title{
Patterns of richness and distribution of Cactaceae in the Serra da Mantiqueira, Southeast Brazil, and implications for its conservation
}

\author{
Diego Rafael Gonzaga ${ }^{2 *}$ (1), Ariane Luna Peixoto ${ }^{2}$ (D) and Luiz Menini Neto ${ }^{3}$ (D)
}

Received: May 11, 2018

Accepted: November 7, 2018

\begin{abstract}
This study aimed to analyze patterns of richness and distribution of Cactaceae in the Serra da Mantiqueira (SM), a mountain range located in Southeast Brazil, and assess its conservation status. We compiled distribution data from the literature and 16 herbaria and plotted it on a map divided into grid squares of $0.5^{\circ}$. Richness, collection effort and similarity among grid squares were analyzed for the 33 taxa recorded in SM (five of which are endemic). Maciço do Itatiaia (in southern SM), Serra do Brigadeiro and Serra do Caparaó (in northern SM) are the richest areas. Collection effort and richness were correlated $\left(\mathrm{R}^{2}=0.75\right)$. Similarity analysis revealed five clusters, one of which is composed of high elevation areas with a vegetation mosaic; the remaining clusters lack biogeographic significance, and are mainly composed of widely distributed species. Ten species had no records in any state or national conservation unit of integral protection, at least two of which are threatened with extinction. Species of Cactaceae deserve attention because several taxa are threatened and/or endemic, and because the majority of SM is environmentally degraded. These findings highlight the need for urgent conservation actions for the local biodiversity os SM.
\end{abstract}

Keywords: Atlantic Forest, campo de altitude, conservation, distribution patterns, species richness

\section{Introduction}

Tropical mountains harbor significant biological diversity (Mutke \& Barthlott 2005; Körner et al. 2016), largely due to the isolation and heterogeneity of habitats and an environmental gradient that often results in high beta diversity (Whittaker et al. 2001; Muenchow et al. 2018) and endemism (Barthlott et al. 2005). This is particularly true for the floristic component (Martinelli 2007; Körner et al. 2016). Distribution patterns are the subject of biogeography and macroecology, and their explanations are quite diverse (Villalobos \& Rangel 2014). Isolation is one of the drivers responsible for the distribution patterns of several taxa in mountains (Körner et al. 2016); however, to investigate such phenomena surveys need to be performed in several areas in order to fill knowledge gaps about species composition. This is true at different scales, such as for Brazil as a whole (Sousa-Baena et al. 2013), for Atlantic phytogeographic domain (Werneck et al. 2011) and for Brazilian mountains (Martinelli 2007).

Serra da Mantiqueira (SM) is a Brazilian mountain range comprising several vegetation physiognomies in the states of Espírito Santo, Minas Gerais, Rio de Janeiro, and São Paulo. It is composed of two main plateaus referred to as the Northern Plateau and the Southern Plateau (MachadoFilho et al. 1983). The area is of special biological importance and is considered a priority for the conservation of springs and endemic species (Drummond et al. 2005; Pelissari \& Romaniuc-Neto 2013; Saout et al. 2013). Given the lack of

1 Part of the Master's thesis in Botany of the first author by Escola Nacional de Botânica Tropical, Instituto de Pesquisas Jardim Botânico do Rio de Janeiro.

2 Programa de Pós-graduação em Botânica, Escola Nacional de Botânica Tropical, Instituto de Pesquisas Jardim Botânico do Rio de Janeiro, 22460-036, Rio de Janeiro, RJ, Brazil

3 Instituto de Ciências Biológicas, Universidade Federal de Juiz de Fora, 36036-330, Juiz de Fora, MG, Brazil

* Corresponding author: diego.gonzaga@gmail.com 


\section{Diego Rafael Gonzaga, Ariane Luna Peixoto \\ and Luiz Menini Neto}

floristic knowledge and the conservation priority for SM, additional botanical collections are needed (Stehmann \& Sobral 2009).

Serra da Mantiqueira has been highly damaged throughout its historical occupation with much of its original vegetation being replaced by forestry or agricultural crops (Mendes Júnior et al. 1991; Pelissari \& Romaniuc-Neto 2013). Burning, deforestation, cultivation on steep slopes and extensive pastures of low productivity are examples of the activities that have shaped Serra da Mantiqueira over the last two centuries (Mendes Júnior et al. 1991). Nonetheless, there are some conservation units in the region, with the main ones being the Itatiaia and Caparaó national parks and Ibitipoca, Serra do Brigadeiro, Serra do Papagaio, Pedra Selada and Campos do Jordão state parks (Gonzaga \& Menini Neto 2017).

Cactaceae comprises 124 genera and about 1438 species, and is almost exclusively distributed in tropical and subtropical America from Canada to Patagonia; Rhipsalis baccifera is the only species that occurs in Africa, Madagascar and Sri Lanka (Hunt et al. 2006). The main centers of diversity and endemism for the family are in Mexico, the Southwest United States, the central region of the Andes - mainly Peru and Bolivia - and eastern Brazil, where it occurs in several types of habitats (Taylor \& Zappi 2004).

Species of Cactaceae are highly affected by anthropic disturbances, which cause rapid habitat destruction that especially affects narrowly distributed endemic taxa. Thirty-one percent of the species of Cactaceae are considered threatened, which reflects the high anthropogenic pressure put on biodiversity in arid lands (Goettsch et al. 2015). There are 39 genera of Cactaceae in Brazil, of which 14 are endemic, encompassing 261 species and 92 subspecies (BFG 2015). They occur in all states and phytogeographic domains of the country, but especially in the Caatinga, Cerrado and Atlantic Forest (Taylor \& Zappi 2004). There are 11 genera and 33 subgeneric taxa of Cactaceae in SM, five of which are endemic and several that are narrowly distributed and threatened due to anthropogenic pressures (Gonzaga 2016). Two of these taxa are cited among the rare plants of Brazil (Machado 2009), while 11 are considered to be in some category of threat (Goettsch et al. 2015).

Taylor \& Zappi (2004) provided descriptions and comments on the geographic distribution and conservation of taxa of Cactaceae for eastern Brazil, while other studies have focused specifically on Serra da Mantiqueira, such as those by Gonzaga et al. (2014a; b; 2015; 2016a; b; 2017), which provided additional knowledge about the distribution of several taxa. Nonetheless, a thorough study dealing with the distribution and conservation of Cactaceae in Serra da Mantiqueira is yet to be realized, even though knowledge of the distribution of organisms is very important for implementing conservation efforts.
Taking this into consideration, the present study seeks to answer the following questions: 1) How are taxa of Cactaceae geographically and altitudinally distributed in Serra da Mantiqueira? 2) What are the most taxonomic rich areas of SM? 3) Are taxonomic richness and collection effort of Cactaceae correlated in SM? 4) Are there any relationships between the regions of SM and the flora of Cactaceae? 5) What are the knowledge gaps in need of being filled for Cactaceae in SM? 6) Which taxa of Cactaceae are protected by comprehensive protection conservation units in SM, and are these taxa listed as threatened with extinction on red lists?

\section{Materials and methods}

\section{Study area}

Different proposals exist for delimiting SM (Mello \& Mello 1909; Várzea 1942; CETEC 1983; Machado-Filho et al. 1983), of which the most recent is followed herein. MachadoFilho et al. (1983) indicated the existence of two main plateaus that encompass an extension of approximately $500 \mathrm{~km}$ : the Northern Plateau and the Southern Plateau (Fig. 1A). The Northern Plateau is composed of the staggered steppes of southern Espírito Santo State, the Maciço of Caparaó, the Serra do Brigadeiro and the Zona da Mata range of the state of Minas Gerais. The Southern Plateau comprises the geomorphological units of the Campos do Jordão and Itatiaia plateaus and is bordered to the north by the high plateau regions of the upper Rio Grande (state of Minas Gerais), to the east by the south-central plateau of Minas Gerais, to the south by the Paraíba do Sul Valley (state of Rio de Janeiro), and to the west by the Amparo plateau (state of São Paulo).

\section{Data collection}

Data on the geographical distribution of Cactaceae in SM were obtained from the literature along with observations of natural populations and analysis of specimens deposited in Brazilian herbaria: BHCB, CESJ, ESALQ*, FCAB, GUA, HB, HUEMG, MBML, R, RB, RBR, SP, SPF, UEC, VIC, and VIES (acronyms according to Thiers 2018). These herbaria were visited or data were obtained from available records in speciesLink (www.splink.org.br; highlighted with an asterisk). Records presented by Gonzaga (2016) with questionable provenance data or referring to cultivated plants [Brasiliopuntia brasiliensis (Willd.) A. Berger; Hylocereus undatus (Haw.) Britton \& Rose; Opuntia ficus-indica (L.) Mill.; and Schlumbergera truncata (Haw.) Moran] were not considered. Records lacking coordinates were georeferenced when possible using the "GeoLoc" tool available in the "Centro de Referência em Informação Ambiental" site (CRIA) (http://splink.cria.org.br/geoloc?criaLANG=pt) or Google Earth (https://www.google.com/earth/). 
Patterns of richness and distribution of Cactaceae in the Serra da Mantiqueira, Southeast Brazil, and implications for its conservation

\section{Spatial analyses}

To evaluate the existence of distribution patterns for Cactaceae in SM, records were plotted on the Americas Base Map (Bletter et al. 2004) with a graticule of $0.5^{\circ} \mathrm{x}$ $0.5^{\circ}$. The Serra da Mantiqueira shapefile was created by the geoprocessing team of the Instituto de Pesquisas Jardim Botânico do Rio de Janeiro, according to the delimitation of Machado-Filho et al. (1983). Richness considered the presence of species of Cactaceae in each grid square while collection effort represented the total number of Cactaceae records in each grid square. A regression analysis was performed to evaluate any correlation between richness and collection effort. The elevation of each record was extracted and the distribution of species of Cactaceae was evaluated along the elevation gradient using 14 elevation belts of $200 \mathrm{~m}$. These analyses were conducted using DIVA-GIS v.7.5 free access software (http://www.diva-gis.org/).

\section{Similarity analysis}

Similarity analysis was performed between grid squares with occurring taxa (Tab. 1) using the UPGMA algorithm (Unweighted Pair-Group Method using Arithmetic Averages), and Jaccard index to verify relationships between
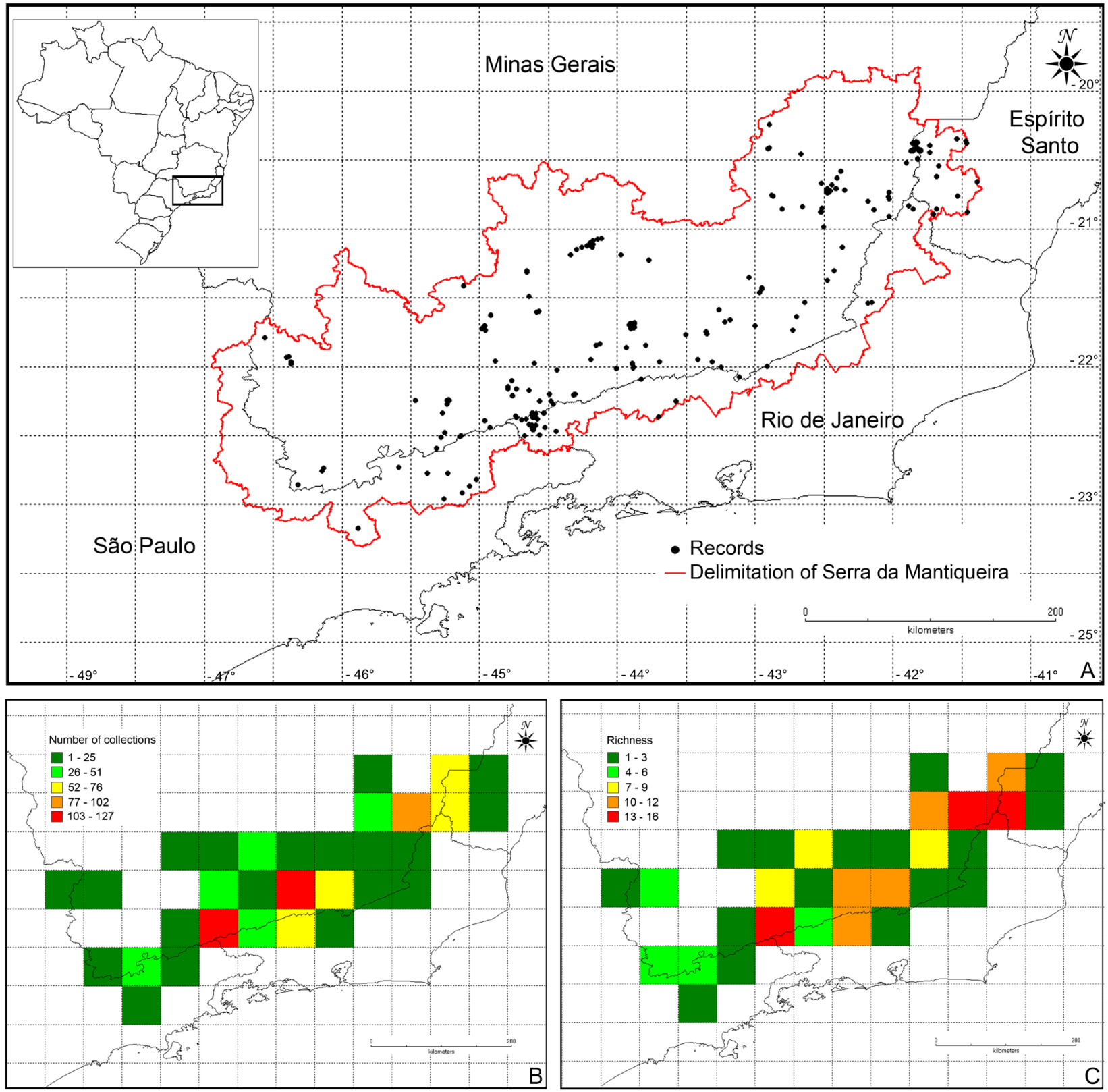

Figure 1. A. Records of Cactaceae in Serra da Mantiqueira; B. Collection effort of Cactaceae in Serra da Mantiqueira; C. Species richness of Cactaceae in Serra da Mantiqueira. Grid squares: $0.5^{\circ}$. 


\section{Diego Rafael Gonzaga, Ariane Luna Peixoto and Luiz Menini Neto}

the SM regions (Fig. 1). A similarity dendrogram was created from a presence (1)/absence (0) matrix, and the cophenetic coefficient calculated, using PAST v. 3 free access software (Hammer et al. 2001).

\section{Conservation}

To determine which taxa are protected and if a reevaluation of extinction risk is needed, especially for SM endemics, records were overlaid with national and state comprehensive protection conservation units and the taxa compared with red lists obtained from MMA (2014) and Goettsch et al. (2015). The shapefiles for the conservation units were obtained at http://www.mma.gov.br.

\section{Results}

\section{Distribution, elevation gradient, richness and collection effort}

Grid squares with records of the presence of Cactaceae had from one (especially in the northwestern border of SM at the ecotone between Atlantic Forest and Cerrado) to 16 (in the Maciço do Itatiaia region) taxa. In general, there were few areas with many taxa, and many areas with few taxa (Fig. 1).

We found three distribution patterns for taxa of Cactaceae in SM: I) taxa widely distributed in SM (found in both plateaus), Cereus fernambucensis subsp. sericifer,

Table 1. Red list category, grids and occurrences in Conservation Units in Serra da Mantiqueira.

\begin{tabular}{|c|c|c|c|c|c|c|c|c|c|c|c|c|}
\hline \multirow[b]{2}{*}{ Taxa } & \multicolumn{2}{|c|}{ Red List Category } & \multirow[b]{2}{*}{ Grids } & \multicolumn{9}{|c|}{ Occurrence in Conservation Units of Integral Protection } \\
\hline & $\begin{array}{l}\text { MMA } \\
\text { (2014) }\end{array}$ & $\begin{array}{c}\text { Goettsch et } \\
\text { al. (2015) }\end{array}$ & & $\begin{array}{c}\text { PNC } \\
\text { (MG/ES) }\end{array}$ & $\begin{array}{c}\text { PNI } \\
\text { (MG/RJ) }\end{array}$ & \begin{tabular}{|l|} 
PEIB \\
(MG)
\end{tabular} & \begin{tabular}{|l} 
PESB \\
(MG)
\end{tabular} & \begin{tabular}{|} 
PESNM \\
(MG)
\end{tabular} & $\begin{array}{l}\text { PESP } \\
\text { (MG) }\end{array}$ & $\begin{array}{l}\text { RSJ } \\
\text { (MG) }\end{array}$ & $\begin{array}{l}\text { PEPS } \\
\text { (RJ) }\end{array}$ & \begin{tabular}{|l} 
PECJ \\
(SP)
\end{tabular} \\
\hline Arthrocereus melanurus subsp. magnus N.P.Taylor \& Zappi * & EN & LC & 3 & - & - & + & - & + & - & - & - & - \\
\hline A. melanurus Diers et al. subsp. melanurus & EN & VU & 4 & - & - & - & - & - & - & + & - & - \\
\hline Cereus fernambucensis subsp. sericifer (Ritter) N.P.Taylor \& Zappi & LC & LC & 3 & - & - & - & - & - & - & - & - & - \\
\hline Coleocephalocereus fluminensis (Miq.) Backeb. & LC & LC & 4 & - & - & - & - & - & - & - & - & - \\
\hline Epiphyllum phyllanthus (L.) Haw. & LC & LC & 9 & - & - & - & - & - & - & - & - & - \\
\hline Hatiora herminiae (Porto \& Castell.) Backeb. ex Barthlott* & LC & EN & 2 & - & - & - & - & - & - & - & - & + \\
\hline Hatiora salicornioides (Haw.) Britton \& Rose & LC & $\mathrm{LC}$ & 16 & + & + & + & + & + & - & + & - & + \\
\hline Hylocereus setaceus (Salm-Dyck) R.Bauer & LC & $\mathrm{LC}$ & 9 & - & - & - & - & - & - & - & - & - \\
\hline Lepismium cruciforme (Vell.) Miq. & LC & LC & 9 & + & - & + & + & - & - & - & - & - \\
\hline L. houlletianum (Lem.) Barthlott & LC & $\mathrm{LC}$ & 9 & + & + & + & - & + & - & + & - & - \\
\hline L. lumbricoides (Lem.) Barthlott & LC & LC & 1 & - & - & - & - & - & - & - & - & - \\
\hline L. warmingianum (K.Schum.) Barthlott & LC & LC & 1 & - & - & - & - & - & - & - & - & - \\
\hline Opuntia monacantha Haw. & LC & LC & 4 & - & - & - & - & + & - & - & - & - \\
\hline Pereskia aculeata Mill. & LC & LC & 5 & - & + & - & + & - & - & - & - & - \\
\hline P. grandifolia Haw. & LC & $\mathrm{LC}$ & 3 & - & - & - & - & - & - & - & - & - \\
\hline Rhipsalis agudoensis N.P.Taylor & LC & $\mathrm{DD}$ & 1 & - & + & - & - & - & - & - & - & - \\
\hline R. campos-portoana Loefgr. & LC & LC & 1 & - & + & - & - & - & - & - & - & - \\
\hline R. clavata F.A.C.Weber & LC & NT & 3 & + & - & - & + & - & - & - & - & - \\
\hline R. crispata (Haw.) Pfeiff. & LC & EN & 1 & - & - & - & - & - & - & - & - & - \\
\hline R. elliptica G.Lindb. ex K.Schum. & LC & LC & 8 & + & + & + & + & + & - & - & + & - \\
\hline R. floccosa subsp. pulvinigera (G.Lindb.) Barthlott \& N.P.Taylor & LC & $\mathrm{LC}$ & 16 & + & + & + & + & + & + & + & - & + \\
\hline R. juengeri Barthlott \& N.P.Taylor & LC & LC & 7 & + & + & + & + & + & - & - & - & - \\
\hline R. lindbergiana K.Schum. & LC & $\mathrm{LC}$ & 18 & + & - & - & - & + & - & - & + & - \\
\hline R. neves-armondii K.Schum. & LC & LC & 1 & - & + & - & - & - & - & - & - & - \\
\hline R. oblonga Loefgr. & LC & VU & 1 & - & - & - & - & - & - & - & - & - \\
\hline R. pachyptera Pfeiff. & LC & LC & 1 & - & - & - & - & - & - & - & - & - \\
\hline R. pilocarpa Loefgr. & LC & VU & 3 & + & + & - & - & + & - & - & - & - \\
\hline R. pulchra Loefgr. & LC & LC & 6 & + & + & + & + & - & + & - & + & + \\
\hline R. teres (Vell.) Steud. & LC & $\mathrm{LC}$ & 5 & + & - & - & - & - & - & - & - & - \\
\hline Schlumbergera kautskyi (Horobin \& McMillan) N.P.Taylor & EN & EN & 3 & + & - & - & + & - & - & - & - & - \\
\hline S. lutea Calvente \& Zappi subsp. lutea* & LC & EN & 1 & - & + & - & - & - & - & - & - & - \\
\hline S. microsphaerica (K.Schum.) Hoevel * & VU & VU & 3 & - & + & - & - & - & - & - & - & - \\
\hline S. opuntioides (Loefgr. \& Dusén) D.R.Hunt * & VU & VU & 5 & - & + & + & - & - & + & - & - & + \\
\hline
\end{tabular}

Red List Category: $\mathrm{CR}=$ Critically Endangered, EN = Endangered, VU = Vulnerable, NT = Near Threatened, LC = Least Concern, DD = Data Deficient. Grids: number of grids with occurrence of the species. PNC: Parque Nacional do Caparaó; PNI: Parque Nacional do Itatiaia; PEIB: Parque Estadual do Ibitipoca; PESB: Parque Estadual da Serra do Brigadeiro; PESNM: Parque Estadual da Serra da Negra da Mantiqueira; PESP: Parque Estadual da Serra do Papagaio; RSJ: Refúgio de Vida Silvestre Libélulas da Serra de São José; PEPS: Parque Estadual da Pedra Selada; PECJ: Parque Estadual de Campos do Jordão. States: ES - Espírito Santo; MG - Minas Gerais; RJ - Rio de Janeiro; SP - São Paulo. * Endemic to Serra da Mantiqueira. 
Coleocephalocereus fluminensis, Epiphyllum phyllanthus, Hatiora salicornioides, Hylocereus setaceus, L. cruciforme, $L$. houlletianum, P. aculeata, P. grandifolia, R. elliptica, R. floccosa subsp. pulvinigera, $R$. juengeri, $R$. lindbergiana, $R$. pilocarpa, R. pulchra, R. teres, S. microsphaerica, S. opuntioides; II) taxa restricted to the Northern Plateau, O. monacantha, R. clavata, $R$. crispata, R. oblonga, R. pachyptera, and S. kautskyi; III) taxa restricted to the Southern Plateau, A. melanurus subsp. magnus, A. melanurus subsp. melanurus, Hatiora herminiae, L. lumbricoides, L. warmingianum, R. agudoensis, R. camposportoana, R. neves-armondii, S. lutea subsp. lutea (Tab. 1).

Arthrocereus melanurus subsp. magnus, Hatiora herminiae, Schlumbergera lutea subsp. lutea, S. microsphaerica and S. opuntioides had the narrowest distributions, being endemic to SM. Schlumbergera lutea subsp. lutea is only known from its type locality (grid square 24) in Maciço do Itatiaia/Mauá, and has not been collected since its discovery. Rhipsalis agudoensis is known from two records in SM - one in Parque Nacional do Itatiaia and one from the district of Penedo - both in the municipality of Itatiaia, state of Rio de Janeiro, and thus its distribution is limited to grid square 24. Lepismium lumbricoides, L. warmingianum, Rhipsalis campos-portoana, R. crispata, $R$. neves-armondii, R. oblonga and $R$. pachyptera are widely distributed throughout the Atlantic Forest, but are known from only one collection site each in SM.

The occurrence of taxa is more common between 600 and $1200 \mathrm{~m}$ (12 taxa). Lepismium cruciforme and R. lindbergiana are the only taxa that occur in the $0-200 \mathrm{~m}$ elevation range. Some species occur at specific elevations, as is the case of Schlumbergera lutea subsp. lutea (401-600 m), Rhipsalis crispata, R. oblonga, R. pachyptera $(601-800 \mathrm{~m})$, R. nevesarmondii (801-1000 m) and R. clavata (1201-1600 m). Rhipsalis pulchra, S. microsphaerica and S. opuntioides reach elevations above $2000 \mathrm{~m}$, while $S$. microsphaerica is the only species to reach the range of 2600-2800 m (Tab. S1 in supplementary material).

The richest regions are represented by grid squares 5,6 and 24 (Fig. 1), with 13, 14, and 16 taxa, respectively. The first two of these grids represent an area bridging Parque Estadual da Serra do Brigadeiro and Parque Nacional do Caparaó at the border of the states of Minas Gerais and Espírito Santo. The last refers to the region of Maciço de Itatiaia at the border of states of Minas Gerais and Rio de Janeiro. Richness and collection effort were found to be positively correlated $\left(R^{2}=0.75, F=88.1, d f=29\right)($ Fig. 1$)$.

\section{Similarity}

The similarity analysis of grid squares resulted in the dendrogram of Figure 2. The cophenetic coefficient was 0.84 , indicating a good fit between the presence/absence matrix and the obtained dendrogram. The dendrogram splits the grids into two groups - one composed of clusters A, $\mathrm{B}, \mathrm{C}$, and $\mathrm{D}$, and one composed of cluster $\mathrm{E}$. The clearest distribution pattern observed is that of cluster $\mathrm{A}$, which was formed by the grid squares $2,4,5,6,13,19$, and 24 , thus grouping high elevation areas together. The vegetation of this cluster is composed of a mosaic of forests (mainly rainforest) and field formations (campos rupestres and campos de altitude). All grids of cluster A share the occurrence of Rhipsalis elliptica and R. lindbergiana, which are commonly found taxa in SM. The cluster also contains the occurrence of endemic taxa to SM: Schlumbergera microsphaerica (grid squares 6 and 24), S. opuntioides (grid squares 19 and 24), S. lutea subsp. lutea (grid square 24) and Arthrocereus melanurus subsp. magnus (grid square 19). The other clusters (B, C, D, and E) are generally composed of geographically unrelated grid squares and mainly share supertramp species (which, consequently, have broad distributions) and/or possess a reduced number of taxa (e.g., grids $1,7,8,12$, 15 and 18 have only one taxon each), and thus do not represent a clear distribution pattern. In spite of the lack of a clear distribution pattern, it is interesting to notice the occurrence of some narrowly-distributed species, such as Hatiora herminiae restricted to grids 28 and 29, Lepismium lumbricoides to grid 28 , L. warmingianum to grid 16 , Rhipsalis crispata to grid 20 and R. oblonga to grid 26.

\section{Conservation}

Twenty-three species have at least one record within at least one of the nine state and national parks considered (Tab. 1). Among the remaining 10 species not recorded inside a CU, Rhipsalis crispata and Rhipsalis oblonga are considered threatened with extinction and are known from only one site in SM - a private area in the municipality of Chácara, Minas Gerais. Some areas represent collection gaps for Cactaceae in SM, especially in the southern region of the state of Minas Gerais where several areas have only a few records (Fig. 1).

\section{Discussion}

The taxa of Cactaceae recorded in SM possess different global patterns of geographical distribution. Some species possess broad distributions throughout South America and are also widely distributed throughout SM, such as E. phyllanthus (common in urban and disturbed areas), Hylocereus setaceus, O. monacantha and P. aculeata. The majority of taxa are endemic to the Atlantic forest domain (Taylor \& Zappi 2004; BFG 2015), but can be broadly distributed within SM (Cereus fernambucensis subsp. sericifer, Coleocephalocereus fluminensis, L. cruciforme, L. houlletianum, $R$. elliptica, $R$. juengeri, R. pilocarpa, R. pulchra, R. teres, $S$. microsphaerica and $S$. opuntioides) or restricted to one of the plateaus (A. melanurus subsp. magnus, Hatiora herminiae, L. lumbricoides, L. warmingianum, R. agudoensis, R. camposportoana, $R$. clavata, $R$. crispata, $R$. neves-armondii, R. oblonga, R. pachyptera, S. kautskyi and S. lutea subsp. lutea). Two of 


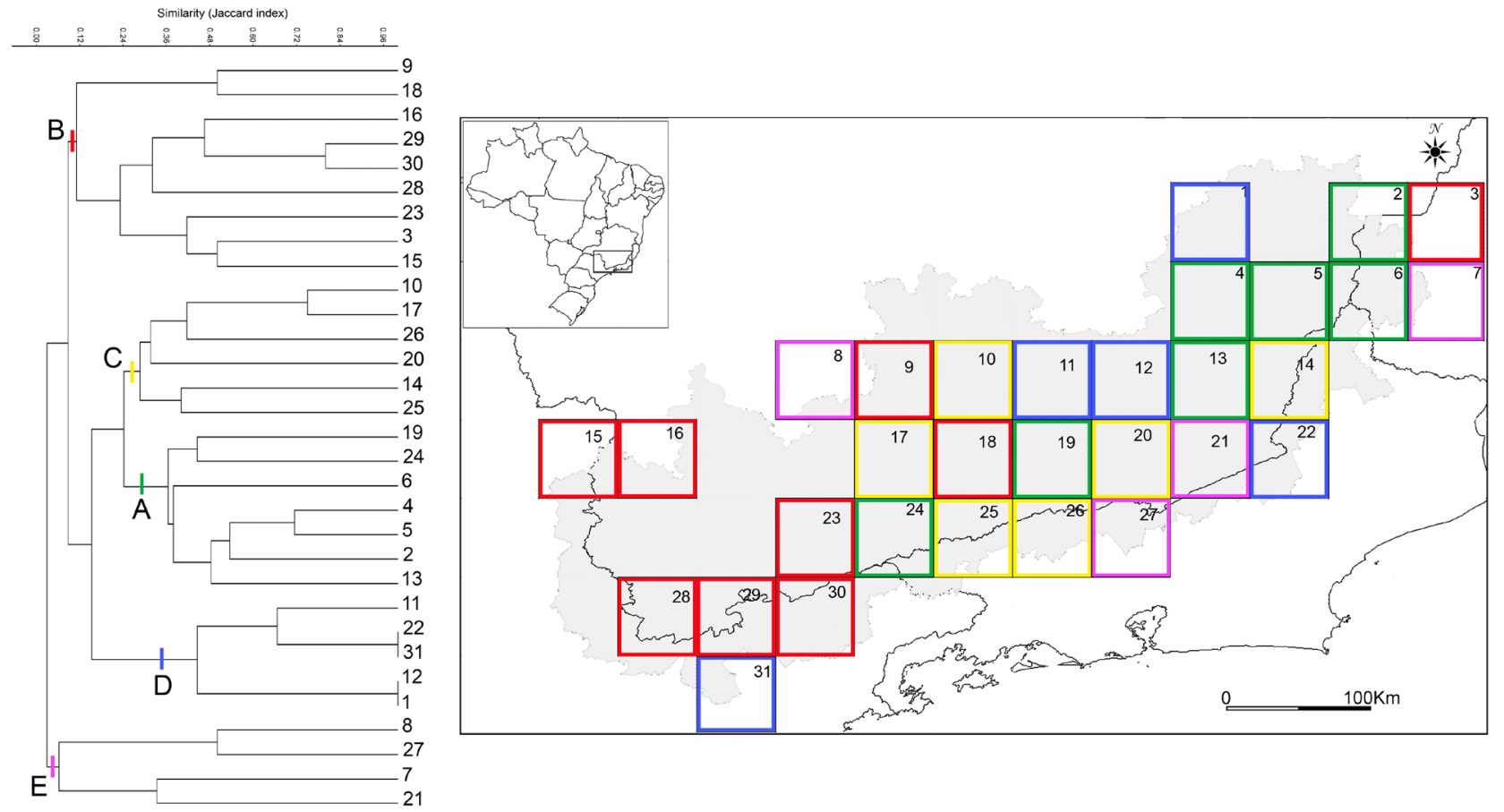

Figure 2. Dendrogram resulting from similarity analysis between grid squares (UPGMA and Jaccard index). Grid squares: $0.5^{\circ}$.

these taxa are restricted to the subtropical region of the South America (i.e., the Southern Cone) - L. lumbricoides and L. warmingianum (Hunt et al. 2006) - both of which are known from one collection in SM (Gonzaga 2016).

The richest areas of SM for Cactaceae were grid squares 5, 6 and 24, which are also areas with several research and educational institutions and thus more thoroughly surveyed. As a result, there is a high correlation between richness and collection effort ( $75 \%)$, which is the so-called 'museum effect', as has been previously cited in other similar studies (e.g., Madeira et al. 2008; Werneck et al. 2011; Sousa-Baena et al. 2013). Grid squares 5 and 6 are part of Northern Plateau of SM, which comprises the regions of Serra do Brigadeiro and Maciço do Caparaó, which are the highest areas of SM. These two areas have been previously studied by researchers from the Universidade Estadual de Minas Gerais (Carangola campus), Universidade Federal de Juiz de Fora, Universidade Federal de Viçosa, and Escola Superior de Agricultura Luiz de Queiroz (Caiafa \& Silva 2005; Soares et al. 2006; Tinti et al. 2015). Maciço do Itatiaia (Southern Plateau of SM) lies in grid square 24, and has been studied by the Instituto de Pesquisas Jardim Botânico do Rio de Janeiro for many decades (Brade 1956; Gonzaga et al. 2017). Other areas of southern Minas Gerais have also been studied previously (França \& Stehmann 2004; Meireles et al. 2008; 2014; Ferreira \& Forzza 2009; Furtado \& Menini Neto 2015; 2016; Santiago et al. 2018).

Despite the aforementioned studies, Stehmann \& Sobral (2009) emphasize that it is important that more surveys be performed in SM, as recent new records for
Cactaceae reinforce - Lepismium lumbricoides (Gonzaga et al. 2016b), Rhipsalis agudoensis (Gonzaga et al. 2016a), $R$. crispata (unpublished data), and R. oblonga (Gonzaga et al. 2015). This is especially true for less studied areas, as evidenced by the lack or scarcity of records for Cactaceae in grid squares of the Southern Plateau of SM.

Data gathered from specific field expeditions (Gonzaga 2016) and from the online database SpeciesLink, enhanced the number of taxa for areas of SM for which surveys have already been published, such as Parque Estadual do Ibitipoca and Parque Estadual da Serra Negra da Mantiqueira (from seven to nine spp. in both areas) (Forzza et al. 2013; Salimena et al. 2013; Gonzaga et al. 2014a; b); Parque Estadual da Serra do Brigadeiro (from four to nine spp.) (Leoni \& Tinte 2004); Parque Nacional do Itatiaia (from seven to 14 spp.) (Brade 1956; Gonzaga et al. 2017); and Parque Nacional do Caparaó (from three to 12 spp.) (Brade 1942; Leoni 1997). These results emphasize the importance of more specific and thorough studies of botanical groups, even in areas that have already had their flora surveyed.

As mentioned previously for Cactaceae, the Northern Plateau of SM was also found to be relevant for Bromeliaceae in Minas Gerais (Versieux \& Wendt 2007), especially the grid square comprising areas of Serra do Brigadeiro and Serra do Caparaó, which further demonstrates the floristic significance of this region. These authors emphasize that the higher elevation and the occurrence of cloud forest supports great epiphytic species richness and abundance. Thus, areas of high elevation and the isolation of SM seem to be responsible for the notable richness and endemism 
of different botanical families, however, the scarcity of information about the distribution of plants in relation to elevation in the Atlantic Forest hinders a better evaluation of distributional patterns (Silva et al. 2016).

The similarity analysis of grid squares resulted in five clusters. Cluster A comprises the richest regions in SM, with a high number of shared taxa (e.g. Rhipsalis agudoensis, $R$. campos-portoana, R. clavata, $R$. neves-armondii, $R$. pachyptera, Schlumbergera kautskyi and S. microsphaerica). It also possesses areas of high elevation and a mosaic of phytophysiognomies composed of both fields (campos rupestres and campos de altitude) and forests (mainly rainforests). These phytophysiognomies are especially well-represented in Ibitipoca and Brigadeiro state parks and Caparaó and Itatiaia national parks, whose floristic relationships have already been highlighted by Abreu et al. (2011), Rezende et al. (2013), Salimena et al. (2013) and Alves \& Menini Neto (2014), and corroborate the results of Versieux \& Wendt (2007) for Bromeliaceae. In general, the remaining clusters did not exhibit a clear distribution pattern, with the grid squares being grouped together mainly due to the presence of widely-distributed generalist taxa, which are also adapted to disturbed environments - the so-called 'supertramp' species (e.g. Epiphyllum phyllanthus, Hylocereus setaceus, Pereskia grandifolia and Rhipsalis lindbergiana) (BFG 2015). Thus, clusters B, C, D and $\mathrm{E}$ are primarily composed of border areas of SM or by grid squares that mainly share generalist species. Collections in areas with knowledge gaps can shed some light on the relationships between areas and the distribution patterns of taxa.

From a conservation standpoint, recent records of two endangered species - R. crispata and R. oblonga (Goettsch et al. 2015) - in SM is noteworthy, both of which were in private areas outside of conservation units. Calvente et al. (2005) and Versieux \& Wendt (2007) emphasize the need for studies in private areas in order to fully assess conservation needs and to provide information for maintaining remnants and species outside of conservation units. Collection efforts, therefore, should be concentrated in areas of SM that lack knowledge of Cactaceae, especially in southern Minas Gerais, to document conserved areas outside conservation units and to better understand the flora.

Three of the five taxa endemic to SM $-A$. melanurus subsp. magnus, H. herminiae, and S. lutea subsp. lutea - are listed under different categories of red lists (MMA 2014; Goettsch et al. 2015). However, it is worth mentioning that Goettsch et al. (2015) did not consider infraspecific taxa, and thus evaluated A. melanurus subsp. magnus and $S$. lutea subsp. lutea together with other subspecies (A. melanurus subsp. melanurus, A. melanurus subsp. odorus and $S$. lutea subsp. Bradei), resulting in wider distributions with more records. MMA (2014) considered the three subspecies of A. melanurus as endangered, which is corroborated by the present study. Despite field efforts to collect $S$. lutea subsp. lutea (Gonzaga 2016), there has been no success, and thus we propose that it be considered 'data deficient', since the type specimen, collected 85 years ago, is the only known record. Hatiora herminiae was previously described as an epiphyte from the plateau of Campos do Jordão (state of São Paulo), but after it was found as rupicolous in Monte Verde (state of Minas Gerais), (both in the Southern Plateau of SM), it was considered 'least concern' by MMA (2014) and 'endangered' by Goettsch et al. (2015), with the latter being the most adequate classification.

Rhipsalis agudoensis is also noteworthy. This taxon was categorized as 'data deficient' by Goettsch et al. (2015), but later revised as 'endangered' by Gonzaga et al. (2016a) based on two records in Maciço do Itatiaia, state of Rio de Janeiro (Southern Plateau of SM). The occurrence of this taxon was later extended to Bananal (state of São Paulo), Sossego do Imbé and Três Rios (state of Rio de Janeiro), and outside the limits of the SM (Taylor \& Hofacker 2017) based on field observations, although no vouchers were indicated.

The gaps of distributional knowledge of Cactaceae found herein represent areas where future effort should be focused to further contribute to the knowledge of the flora of SM and Brazil. Such effort would also provide important support to studies of distribution patterns and conservation of both species of Cactaceae and SM. Some endemic species must be carefully reevaluated for future red lists of Brazilian flora, especially considering that the rapid rate of degradation of SM - caused by crops, cattle livestock, burning, realestate speculation, disordered tourism — can lead to their extinction.

\section{Acknowledgements}

The authors wish to thank CAPES and FAPERJ for the study grants to DRG; ICMBio and IEF for the research license; and to the curators and employees of the consulted herbaria. We also thank the Editor (Dr. Elder Paiva) and the anonymous reviewers who have given their time to contribute to qualifying the final text. This study was financed in part by the Coordenação de Aperfeiçoamento e Pessoal de Nível Superior - Brasil (CAPES) - Finance Code 001.

\section{References}

Abreu NL, Menini Neto L, Konno TUP. 2011. Orchidaceae das Serras Negra e do Funil, Rio Preto, Minas Gerais, e similaridade florística entre formações campestres e florestais do Brasil. Acta Botanica Brasilica 25: 58-70.

Alves F, Menini Neto L. 2014. Vascular epiphytes in a forest fragment of Serra da Mantiqueira and floristic relationships with Atlantic high altitude areas in Minas Gerais. Brazilian Journal of Botany 37: 187-196.

Barthlott W, Mutke J, Rafiqpoor D, Kier G, Kreft H. 2005. Global centers of vascular plant diversity. Nova Acta Leopoldina 92: 61-83.

BFG - The Brazilian Flora Group. 2015. Growing knowledge: an overview of seed plant diversity in Brazil. Rodriguésia 66: 1085-1113. 


\section{Diego Rafael Gonzaga, Ariane Luna Peixoto and Luiz Menini Neto}

Bletter N, Janovec J, Brosi B, Douglas CD. 2004. A digital base map for studying the Neotropical flora. Taxon 53: 469-477.

Brade AC. 1942. Excursão a Serra do Caparaó. Rodriguésia 6: 87-92.

Brade AC. 1956. A flora do Parque Nacional do Itatiaia. Boletim do Parque Nacional do Itatiaia 5: 7-85.

Caiafa AN, Silva AF. 2005. Composição florística e espectro biológico de um campo de altitude no Parque Estadual da Serra do Brigadeiro, Minas Gerais-Brasil. Rodriguésia 56: 163-173.

Calvente AM, Freitas MF, Andreata RHP. 2005. Listagem, distribuição geográfica e conservação das espécies de Cactaceae no Estado do Rio de Janeiro. Rodriguésia 56: 141-162.

CETEC - Fundação Centro Tecnológico de Minas Gerais. 1983. Diagnóstico ambiental de Minas Gerais. Vol. 1. Belo Horizonte, CETEC.

Drummond GM, Martins CS, Machado ABM, Sebaio FA, Antonini Y. (Orgs.). 2005. Biodiversidade em Minas Gerais: um atlas para sua conservação. 2nd. edn. Belo Horizonte, Fundação Biodiversitas.

Ferreira FM, Forzza RC. 2009. Florística e caracterização da vegetação da Toca dos Urubus, Baependi, Minas Gerais, Brasil. Biota Neotropica 9: 131-148.

Forzza RC, Menini Neto L, Salimena FRG, Zappi D. 2013. Flora do Parque Estadual do Ibitipoca e seu entorno. Juiz de Fora, Editora UFJF.

França GS, Stehmann JR. 2004. Composição florística e estrutura do componente arbóreo de uma floresta altimontana no município de Camanducaia, Minas Gerais, Brasil. Revista Brasileira de Botânica 27: 19-30.

Furtado SG, Menini Neto L. 2015. Diversity of vascular epiphytes in two high altitude biotopes of the Brazilian Atlantic Forest. Brazilian Journal of Botany 38: 295-310.

Furtado SG, Menini Neto L. 2016. Vascular epiphytic flora of a high montane environment of Brazilian Atlantic Forest: composition and floristic relationships with other ombrophilous forests. Acta Botanica Brasilica 30: 422-436.

Goettsch B, Hilton-Taylor C, Cruz-Piñón G, et al. 2015. High proportion of cactus species threatened with extinction. Nature Plants 1: 1-7.

Gonzaga DR. 2016. Cactaceae na Serra da Mantiqueira, Brasil: Taxonomia, biogeografia e conservação. MSc Thesis, Instituto de Pesquisas Jardim Botânico do Rio de Janeiro, Rio de Janeiro.

Gonzaga DR, Barbosa DEF, Basílio GA, Silva FR, Menini Neto L. 2015. First record of Rhipsalis oblonga (Cactaceae), a threatened plant species, in Minas Gerais state, Brazil. Check List 11: 1699.

Gonzaga DR, Menini Neto L. 2017. Estado de conservação da Serra da Mantiqueira: Ameaças, lacunas, avanços e perspectivas do conhecimento da flora. In: Barbosa BC, Resende LO, Prezoto F, Gonçalves EL. (Orgs.). Tópicos em sustentabilidade e conservação. 1st. edn. Juiz de Fora, Real Consultoria de Negócios Ltda. p. $77-86$.

Gonzaga DR, Menini Neto L, Peixoto AL. 2016b. First record of Lepismium lumbricoides (Lem.) Barthlott (Cactaceae), in Minas Gerais state, Brazil. Cactus and Succulent Journal 88: 177-181.

Gonzaga DR, Menini Neto L, Peixoto AL. 2017. Cactaceae no Parque Nacional do Itatiaia, Serra da Mantiqueira, Brasil. Rodriguésia 68: 1397-1410.

Gonzaga DR, Moraes L, Menini Neto L, Peixoto AL. 2016a. Rediscovery, considerations about type locality and conservation of Rhipsalis agudoensis (Cactaceae) from the Brazilian Atlantic Forest. Phytotaxa 278: 74-78.

Gonzaga DR, Zappi DC, Furtado SG. \& Menini Neto L. 2014a. Cactaceae no Parque Estadual de Ibitipoca, Minas Gerais Brasil. Boletim de Botânica da Universidade de São Paulo 32: 1-8.

Gonzaga DR, Zappi DC, Furtado SG, Menini Neto L. 2014b. Cactaceae na Serra Negra, Minas Gerais Brasil. Rodriguésia 65: 443-453.

Hammer Ø, Harper DAT, Ryan PD. 2001. PAST: paleontological statistics software package for education and data analysis. Palaeontologia Electronica 4: 1-9.

Hunt D, Taylor N, Charles G. 2006. The new cactus lexicon. Milborne Port, DH books.

Körner C, Paulsen J, Spehn EM. 2016. A definition of mountains and their bioclimatic belts for global comparisons of biodiversity data. Alpine Botany 121: 73-78.
Leoni LS. 1997. Catálogo preliminar das fanerógamas ocorrentes no Parque Nacional do Caparaó-MG. Pabstia 8: 1-28

Leoni LS, Tinte VA. 2004. Flora do Parque Estadual da Serra do Brigadeiro, estado de Minas Gerais, Brasil - Caracterização da vegetação e lista preliminar das espécies. Carangola, Gráfica São José.

Machado MC. 2009. Cactaceae. In: Giulietti AM, Rapini A, Andrade MJG, Queiroz LP, Silva JMC. Plantas raras do Brasil. Belo Horizonte, Conservação Internacional, Universidade Estadual de Feira de Santana. p. 118-126.

Machado-Filho L, Ribeiro MW, Gonzalez SR, et al. 1983. Geologia. In: Projeto RADAMBRASIL Vol. 32. Folhas SF 23/24 Rio de Janeiro/ Vitória, MEE/SG. p.56-66.

Madeira JA, Ribeiro KT, Oliveira MJR, Nascimento JS, Paiva CL. 2008. Distribuição espacial do esforço de pesquisa biológica na Serra do Cipó, Minas Gerais: Subsídios ao manejo das unidades de conservação da região. Megadiversidade 4: 257-271.

Martinelli G. 2007. Mountain biodiversity in Brazil. Revista Brasileira de Botânica 30: 587-597.

Meireles LD, Shepherd GJ, Kinoshita LS. 2008. Variações na composição florística e na estrutura fitossociológica de uma floresta ombrófila densa alto-montana na Serra da Mantiqueira, Monte Verde, MG. Revista Brasileira de Botânica 31: 559-574.

Meireles LD, Kinoshita LS, Shepherd GJ. 2014. Composição florística da vegetação altimontana do distrito de Monte Verde (Camanducaia, MG), Serra da Mantiqueira Meridional, Sudeste do Brasil. Rodriguésia 65: 831-859

Mello H, Mello FH. 1909. Atlas do Brazil. Rio de Janeiro, F. Briguiet \& Cia. Editores

Mendes Júnior LO, Antoniazzi M, Vieira MCW, Susemihl P. 1991. Relatório Mantiqueira. São Paulo, FEDAPAM.

MMA - Ministério do Meio Ambiente. 2014. Lista nacional oficial de espécies da flora ameaçadas de extinção. Portaria MMA 443, 17 de dezembro de 2014. http://cncflora.jbrj.gov.br/portal/static/pdf/ portaria_mma_443_2014.pdf. 28 Oct. 2018.

Muenchow J, Dieker P, Kluge J, Kessler M, Wehrden H. 2018. A review of ecological gradient research in the Tropics: identifying research gaps, future directions, and conservation priorities. Biodiversity and Conservation 27: 273-285.

Mutke J, Barthlott W. 2005. Patterns of vascular plant diversity at continental to global scales. Biologiske Skrifter 55: 521-531.

Pelissari G, Romaniuc-Neto S. 2013. Ficus (Moraceae) da Serra da Mantiqueira, Brasil. Rodriguésia 64: 91-111.

Rezende MG, Elias RCL, Salimena FRG, Menini Neto L. 2013. Flora vascular da Serra da Pedra Branca, Caldas, Minas Gerais e relações florísticas com áreas de altitude da Região Sudeste do Brasil. Biota Neotropica 13: 201-224.

Salimena FRG, Matozinhos CR, Abreu NL, Ribeiro JHC, Souza FS, Menini Neto L. 2013. Flora fanerogâmica da Serra Negra, Minas Gerais, Brasil. Rodriguésia 64: 311-320.

Santiago DS, Oliveira-Filho AT, Menini Neto L, Carvalho FA, Salimena FRG. 2018. Floristic composition and phytogeography of an Araucaria Forest in the Serra da Mantiqueira, Minas Gerais, Brazil. Rodriguésia 69: 1909-1925.

Saout S, Hoffmann M, Shi Y, et al. 2013. Protected areas and effective biodiversity conservation. Science 342: 803-805.

Silva ED, Tozzi AMGA, Meireles LD. 2016. Leguminosae in an altitudinal gradient in the Atlantic Forest of Serra do Mar State Park, São Paulo, Brazil. Biota Neotropica 16: 1-15.

Soares MP, Saporetti Junior AW, Meira Neto JAA, Silva AF, Souza AL. 2006. Composição florística do estrato arbóreo de Floresta Atlântica interiorana em Araponga - Minas Gerais. Revista Árvore 30: 859-870.

Sousa-Baena MS, Garcia LC, Peterson AT. 2013. Completeness of digital accessible knowledge of the plants of Brazil and priorities for survey and inventory. Diversity and Distributions 20: 369-381.

Stehmann JR, Sobral M. 2009. Fanerógamas. In: Drummond GM, Martins CS, Greco MB, Vieira F. (Orgs.). Biota Minas. Diagnóstico do conhecimento sobre a biodiversidade no estado de Minas Gerais: conservação, uso e biotecnologia. Belo Horizonte, Fundação Biodiversitas. p. 355-374. 
Taylor NP, Hofacker A. 2017. Rhipsalis agudoensis - a mystery solved. Bradleya 35: 248-251.

Taylor NP, Zappi DC. 2004. Cacti of Eastern Brazil. Kew, Royal Botanic Gardens.

Thiers B. 2018. Index Herbariorum: A global directory of public herbaria and associated staff. New York, New York Botanical Garden's Virtual Herbarium. http://sweetgum.nybg.org/ih/

Tinti BV, Schaefer CERG, Nunes JA, Rodrigues AC, Fialho IF, Neri AV. 2015. Plant diversity on granite/gneiss rock outcrop at Pedra do Pato, Serra do Brigadeiro State Park, Brazil. Check List 11: 1-8.

Várzea A. 1942. Relevo do Brasil. Revista Brasileira de Geografia 4: 97-130.
Versieux LM, Wendt T. 2007. Bromeliaceae diversity and conservation in Minas Gerais state, Brazil. Biodiversity and Conservation 16: 2989-3009.

Villalobos F, Rangel TF. 2014. Geographic patterns of biodiversity. In: Benítez M, Miramontes O, Valiente-Banuet A (eds.) Frontiers in ecology, evolution and complexity. Mexico City, CopIt-arXives. p. 1-11. Werneck MS, Sobral MEG, Rocha CTV, Landau EC, Stehmann JR. 2011. Distribution and endemism of angiosperms in the Atlantic Forest. Natureza \& Conservação 9: 188-193.

Whittaker RJ, Willis KJ, Field R. 2001. Scale and species richness: towards a general, hierarchical theory of species diversity. Journal of Biogeography 28: 453-470. 